\title{
The Lafitte Mound Site (41SY15) in the Middle Sabine River Basin, Shelby County, Texas
}

Timothy K. Perttula

Heritage Research Center, Stephen F. Austin State University

Follow this and additional works at: https://scholarworks.sfasu.edu/ita

Part of the American Material Culture Commons, Archaeological Anthropology Commons, Environmental Studies Commons, Other American Studies Commons, Other Arts and Humanities Commons, Other History of Art, Architecture, and Archaeology Commons, and the United States History Commons

Tell us how this article helped you.

This Article is brought to you for free and open access by the Center for Regional Heritage Research at SFA ScholarWorks. It has been accepted for inclusion in Index of Texas Archaeology: Open Access Gray Literature from the Lone Star State by an authorized editor of SFA ScholarWorks. For more information, please contact cdsscholarworks@sfasu.edu. 
The Lafitte Mound Site (41SY15) in the Middle Sabine River Basin, Shelby County, Texas

\section{Creative Commons License}

\section{(c) (1) (8)}

This work is licensed under a Creative Commons Attribution-NonCommercial 4.0 International License 


\section{The Lafitte Mound Site (41SY15) in the Middle Sabine River Basin, Shelby County, Texas}

\section{Timothy K. Perttula}

\section{INTRODUCTION}

The Lafitte site (41SY15) is an ancestral Caddo mound center in the middle Sabine River basin in the East Texas Pineywoods (Figure 1). It was identified and recorded in the early 1960s during the course of archaeological surveys of then proposed Toledo Bend Reservoir (Scurlock 1964; Scurlock and Davis 1962).

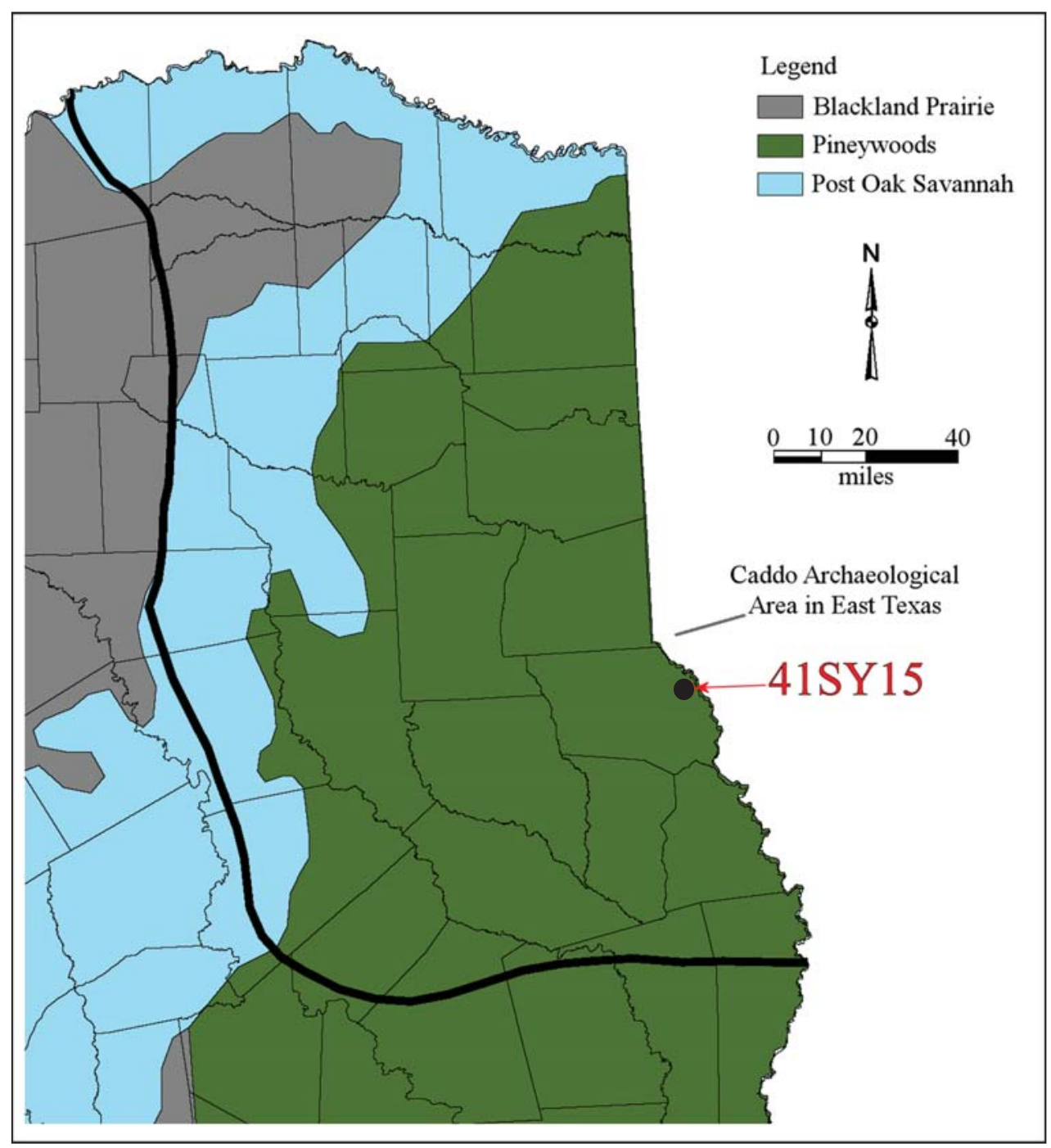

Figure 1. The location of the Lafitte site (41SY15) in East Texas. 


\section{SITE SETTING AND ARCHAEOLOGICAL INVESTIGATIONS}

The Lafitte site is situated on the crest of an isolated upland ridge (ca. 270 feet amsl) that would have overlooked the Sabine River floodplain a few miles to the east (Figure 2) and ca. $100 \mathrm{ft}$. lower in elevation. Its location on a prominent upland landform, with "a commanding view of the territory" (Middlebrook 2014:89) is similar to the placement of other "important local Caddo ceremonial centers" in this part of East Texas.

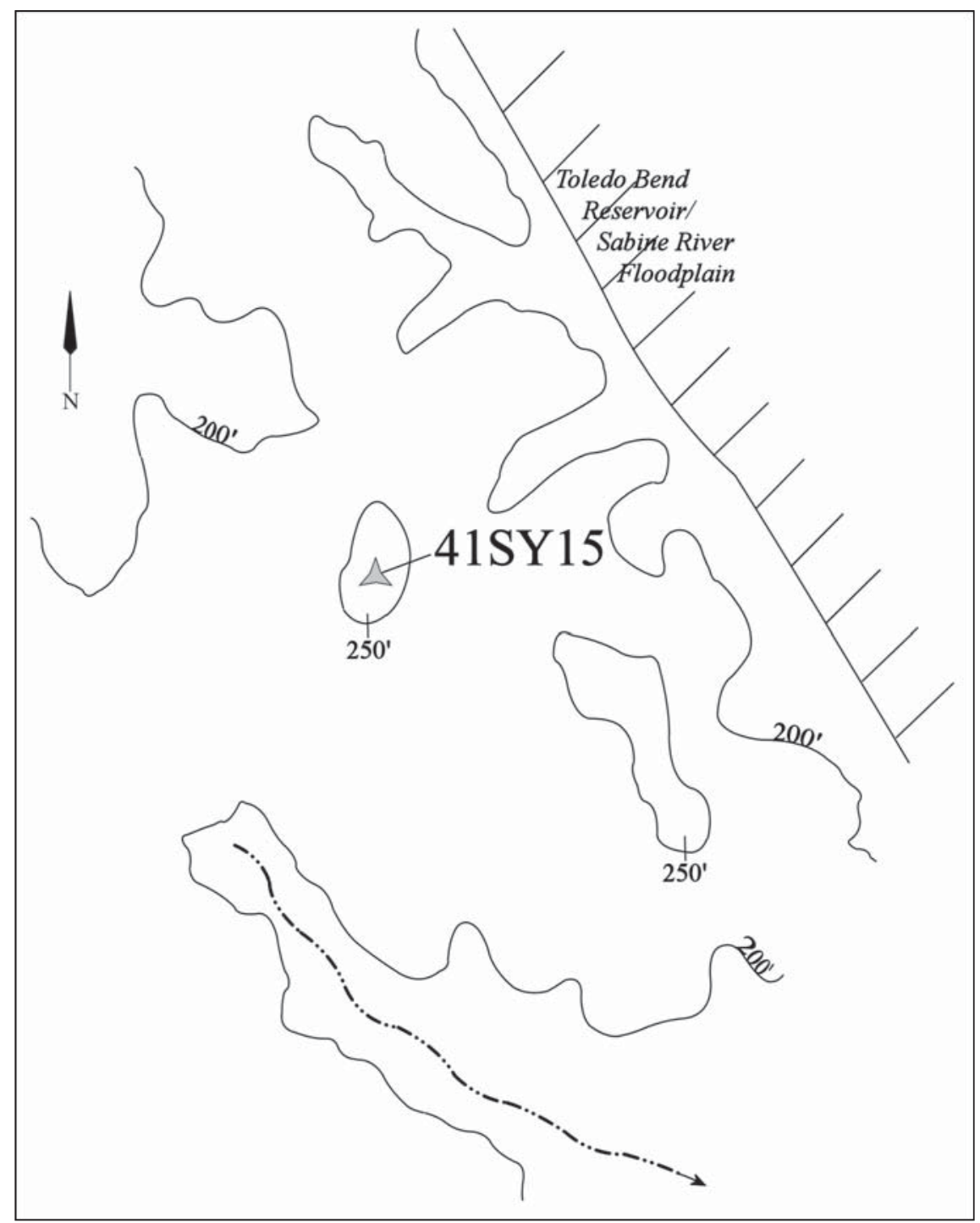

Figure 2. The topographic setting of the Lafitte site in the uplands west of the Sabine River floodplain.

J. Dan Scurlock located the site in the Spring of 1962. He estimated the site covered a ca. 40 x $25 \mathrm{~m}$ area, but excavated no shovel tests to try to determine the areal extent of subsurface archaeological deposits at the site. The cultural features of note at the site included two earthen mounds not far from each other. The first was ca. $9.2 \mathrm{~m}$ in diameter and ca. $1.5 \mathrm{~m}$ in height, while the other was $15.2 \mathrm{~m}$ in diameter and ca. 0.9 $\mathrm{m}$ in height. Ancestral Caddo pottery sherds was recovered to the south of the mounds.

Although Scurlock did not investigate the two mounds, their size and shape are consistent with deliberately constructed Caddo earthen mounds in East Texas. The Lafitte site may be the southernmost and 
easternmost of the known multiple Caddo mound centers in East Texas (Perttula 2004:Figure 13.26). The mounds may have been built to cover important structures, serve as platforms for important buildings, or were constructed to cover burial pits of the political and religious elite in a local Caddo community (cf. Middlebrook 2014:100).

\section{RECOVERED ARCHAEOLOGICAL MATERIAL REMAINS}

Only a handful of artifacts were collected by Scurlock from the Lafitte site. The artifacts included one red chert bipolar core and 19 ceramic sherds from Caddo vessels. These sherds were primarily from bonetempered vessels (74 percent), while the other sherds are from grog-tempered vessels.

Eleven of the sherds are plain body sherds, but eight rim or body sherds have decorative elements. The rim is from a bone-tempered carinated bowl with broad horizontal and vertical excised areas under the lip and on the rim itself, but no clear decorative elements. The other seven decorated sherds are body sherds from wet paste utility ware jars. Three of these sherds ( 43 percent of the utility ware sherds) have parallel brushing marks, three others have parallel incised lines, and one has a row of tool punctations.

The high proportions of bone-tempered vessel sherds as well as the frequency of brushed utility ware sherds (albeit given the very small size of the ceramic assemblage) in the Lafitte site ceramic assemblage suggests that the site dates to the Late Caddo (ca. A.D. 1400-1680) period. There are a number of such sites in the mid-Sabine and Angelina River basins (see Perttula 2015:Figure 11), and in fact, these sites are part of a recently identified Late Caddo bone-tempered and brushed ceramic tradition in East Texas. Based on investigations at the nearby Morse Mound site (41SY27), also a Caddo multiple mound center (Bruseth et al. 2000; Middlebrook 2014), and the analysis of the ceramic assemblage from mound and village contexts (Perttula and Selden 2014), it is likely that the Morse Mound and Lafitte sites were occupied contemporaneously by Caddo groups. Mean calibrated radiocarbon ages from two samples (Middlebrook 2014:100) from the Morse Mound site, as well as the results of OCR analysis of sediment samples from mound and habitation contexts (Frink and Perttula 2001) at the site, indicate it was occupied by Caddo peoples from the late 15 th century A.D. to the early 16 th century A.D.

\section{CONCLUSIONS}

The available archaeological evidence gathered in the early 1960s during the course of the archaeological survey of then proposed Toledo Bend Reservoir indicates that the Lafitte site is an ancestral Caddo mound center with two mounds that range in diameter from 9.2-15.2 $\mathrm{m}$ and ranged in height from 0.9-1.5 m. The function of these two mounds are not known, but their construction here, on a prominent upland ridge, suggests that the Lafitte site was an important local Caddo ceremonial center. The character of the few plain and decorated ceramic sherds found at the Lafitte site, and comparisons with the ceramic assemblage from the better studied and nearby Morse Mound site (41SY27), which also has radiocarbon and OCR dates, further suggests that the Lafitte site was occupied by Caddo peoples from the late 15th century A.D. to the early 16 th century A.D.

\section{ACKNOWLEDGMENTS}

I thank Jonathan Jarvis at the Texas Archeological Research Laboratory at The University of Texas at Austin for facilitating access to the Lafitte site collections and records. Lance Trask prepared the figures for this article. 


\section{REFERENCES CITED}

Bruseth, J., M. Parsons, T. Middlebrook, and B. Martin

2000 Unprecedented Find Uncovered at the Ronald and Kay Morse Site (41SY27). Current Archeology in Texas 2(1):4-7.

Frink, D. and T. K. Perttula

2001 Analysis of the 39 Oxidizable Carbon Ratio Dates from Mound A, Mound B, and the Village Area at the Calvin Davis or Morse Mounds Site (41SY27). North American Archaeologist 22(2):143-160.

Middlebrook, T. A.

2014 Early European Descriptions of Hasinai Elites and Understanding Prehistoric Caddo Mortuary Practices in Shelby County, Texas. Bulletin of the Texas Archeological Society 85:83-110.

Perttula, T. K.

2004 The Prehistoric and Caddoan Archeology of the Northeast Texas Pineywoods. In The Prehistory of Texas, edited by T. K. Perttula, pp. 370-407. Texas A\&M University Press, College Station.

2015 East Texas Caddo Ceramic Sherd Database. Journal of Northeast Texas Archaeology 51:1-46.

Perttula, T. K. and R. Z. Selden Jr.

2014 Ceramic Sherds from the Morse Mounds Site (41SY27). Center for Regional Heritage Research, Research Report No. 3. Stephen F. Austin State University, Nacogdoches.

Scurlock, J. D.

1964 Archeological Reconnaissance at Toledo Bend Reservoir, 1962-1963 Season. Texas Archeological Salvage Project, The University of Texas at Austin.

Scurlock, J. D. and W. A. Davis

1962 Appraisal of the Archeological Resources of Toledo Bend Reservoir, Panola, Newton, Sabine, and Shelby Counties, Texas; Sabine and DeSoto Parishes, Louisiana. Texas Archeological Salvage Project, The University of Texas at Austin. 